\title{
Protamine-like proteins have bactericidal activity. The first evidence in Mytilus galloprovincialis
}

\author{
Rosaria Notariale1, Adriana Basile1, Elena Montana1, Nunzia Colonna Romano1, Maria Grazia \\ Cacciapuoti1, Francesco Aliberti1, Renato Gesuele1, Francesca De Ruberto1, Sergio Sorbo², \\ Gian Carlo Tenore ${ }^{3}$, Marco Guida1,2, Katrina V. Good4, Juan Ausió ${ }^{4}$ and Marina Piscopo ${ }^{\bowtie}$
}

\begin{abstract}
'Department of Biology, University of Naples Federico II, Naples, Italy; ${ }^{2}$ Ce.S.M.A, Section of Microscopy, University of Naples Federico II, Complesso University Monte Sant'Angelo, Via Cinthia 4, 80126 Napoli, Italy; 'Department of Pharmacy, University of Naples "Federico II", Naples, Italy; ${ }^{4}$ University of Victoria, Department of Biochemistry \& Microbiology, Victoria, British Columbia, Canada
\end{abstract}

The major acid-soluble protein components of the mussel Mytilus galloprovincialis sperm chromatin consist of the protamine-like proteins PL-II, PL-III and PL-IV, an intermediate group of sperm nuclear basic proteins between histones and protamines. The aim of this study was to investigate the bactericidal activity of these proteins since, to date, there are reports on bactericidal activity of protamines and histones, but not on protaminelike proteins. We tested the bactericidal activity of these proteins against Gram-positive bacteria: Enterococcus faecalis and two different strains of Staphylococcus aureus, as well as Gram-negative bacteria: Proteus mirabilis, Proteus vulgaris, Pseudomonas aeruginosa, Salmonella typhmurium, Enterobacter aerogenes, Enterobacter cloacae, and Escherichia coli. Clinical isolates of the same bacterial species were also used to compare their sensitivity to these proteins. The results show that Mytilus galloprovincialis protamine-like proteins exhibited bactericidal activity against all bacterial strains tested with different minimum bactericidal concentration values, ranging from 15.7 to $250 \mu \mathrm{g} / \mathrm{mL}$. Furthermore, these proteins were active against some bacterial strains tested that are resistant to conventional antibiotics. These proteins showed very low toxicity as judged by red blood cell lysis and viability MTT assays and seem to act both at the membrane level and within the bacterial cell. We also tested the bactericidal activity of the product obtained from an in vitro model of gastrointestinal digestion of protaminelike proteins on a Gram-positive and a Gram-negative strain, and obtained the same results with respect to undigested protamine-like proteins on the Gram-positive bacterium. These results provide the first evidence of bactericidal activity of protamine-like-proteins.

Key words: bactericidal activity; sperm proteins; protamine-like-proteins; Mytilus galloprovincialis; Gram positive and negative bacteria; natural molecules

Received: 27 June, 2018; revised: 09 November, 2018; accepted: 12 November, 2018; available on-line: 18 November, 2018

e-mail: piscopo@unina.it

Abbreviations: PL-Proteins, protamine-like proteins; AU-PAGE, acetic acid urea-polyacrylamide gel electrophoresis; WHD, wingedhelix domain; EMSA, electrophoretic mobility shift assay; REMSA, RNA electrophoretic mobility shift assay; MH, Mueller Hinton; PCA, perchloric acid

\section{INTRODUCTION}

Antibiotic resistant bacteria represent an important threat to public health that requires a prompt develop- ment of new antibiotics to replace those that become ineffective. Much work has been devoted to developing highly efficient compounds that are also less susceptible to the development of resistance by bacteria. Over the past two decades it has been necessary to search for natural products as sources of new bactericidal agents (Tepe et al., 2004).

Peptides and proteins with bactericidal activity are recognized as important components of the innate defense system and are produced from both prokaryotes and eukaryotes, including fungi, plants (Basile et al., 2017; Piscopo et al., 2018a), invertebrates and vertebrates (Tepe et al., 2004; Wang, 2014).

Several bioactive compounds have been identified in marine organisms which represent a large reservoir for pharmacologically potent and active drugs that evolved to deal with extremely difficult, competitive, and aggressive constraints of the environment in which they live (Piscopo et al., 2018b; Maresca et al., 2018), and which are very different compared to those in terrestrial environments (Conte et al., 2017). Cationic compounds have been demonstrated as potential candidates for new bactericidal agents since they have a low potential for the development of resistance (Carmona-Ribeiro et al., 2013). Moreover, histones for example have displayed potent bactericidal activity in many organisms as both, intact proteins or cleaved peptides (Poirier et al., 2014; Rose-Martel et al., 2014). There is also evidence in the literature about the bactericidal properties of protamines, such as clupeine and salmine, herring and salmon protamines, that exhibit activity against some pathogenic Gram-positive and Gram-negative bacteria, respectively (Potter et al., 2005; Miura et al., 2010). However, nothing has been presented to date on the bactericidal activity of protamine-like proteins (PL-proteins), which are one of the three types of Sperm Nuclear Basic Proteins (SNBPs) and represent a structurally and functionally intermediate group of proteins between the histone $(\mathrm{H})$ and protamine $(\mathrm{P})$ type (Ausió, 1999). These proteins are related to histone H1 and are arginine-and lysine-rich (Fioretti et al., 2012; Piscopo et al., 2010). They were first described in bivalve mollusks but later have been also found in echinoderms, tunicates, and vertebrates (Ausió, 1995; Eirin-Lo'pez et al., 2006). Two main PL-protein subtypes exist: those referred to as PL-I, whose structure consists of a winged-helix domain (WHD), as well as Branchiostoma's PL (Eirin-Lo'pez et al., 2006) and Mytilus PL-III that lack this domain (Eirin-Lo' pez et al., 2006). Low molecular weight PL-proteins lacking the WHD have only been described in the invertebrate organisms (Eirin-Lo'pez et al., 2008). In the sperm chromatin of M. galloprovincialis, 
which is considered to be a Mediterranean derivative of M. edulis (Barsotti et al., 1968), three types of proteins are associated with the sperm DNA: (1) the PL-proteins: PLII, PL-III, and PL-IV (76\% of the overall nuclear protein composition); (2) the four core histones (20\%); and (3) three non-histone proteins tightly bound to DNA (4\%) (Ausió, 1986; Lewis \& Ausió, 2002). Sperm nuclear protein composition has been thoroughly studied and shown to be extremely conserved throughout all Mytilus species that have been studied so far and which include: galloprovincialis, edulis, califotrnianuus and trossulus (Ausió \& Subirana, 1982; Ausió \& McParland, 1989; Mogensen et al., 1991; Rocchini et al., 1995). The three PL-proteins were previously known as: $\varphi 2 \mathrm{~B}$ (PL-II), $\varphi$ 1(PL-III) and $\varphi 3$ (PL-IV) (Ausió et al., 1982).

The percentage of the three individual PL-proteins in reference to overall total nuclear proteins is the following: PL-III (50\%), PL-II (20\%) and PL-IV (6\%) (Lewis and Ausió, 2002), while their molecular weights are 11.3 $\mathrm{kDa}, 14 \mathrm{kDa}$, and $6.5 \mathrm{kDa}$, respectively.

M. galloprovincialis PL-II $(14 \mathrm{kDa})$ contains a conserved globular core of 84 amino acid residues that has a high structural similarity to histone H1 WHD (Carlos et al., 1993a). PL-IV protein $(6.5 \mathrm{kDa})$ has a highly lysine-rich composition similar to that of the somatic histone H1 C-terminal tail (Phelan et al., 1974). PL-III protein (11.3 $\mathrm{kDa}$ ), rich in both lysine and arginine, is intermediate between histones and protamines and, like protamines, lacks any specific secondary structure in vitro (Rocchini et al., 1995; Carlos et al., 1993a) and possesses sequence similarity with the N-terminal region of Spisula PL-I (Lewis et al., 2004). PL-II and PL-IV are derived from a post-translational cleavage of a common (PL-I) precursor (Carlos et al.,1993b) whereas PL-III derives from an independent gene product (Lewis et al., 2002).

In this study, we investigated the bactericidal activity on different Gram-positive and Gram-negative bacteria of individually purified $M$. galloprovincialis PL-proteins, as well as that of the crude extract containing the three PL-proteins, obtained by extraction with $5 \%$ perchloric acid (PCA) from spermatozoa. Furthermore, we evaluated the toxicity of these proteins and investigated their action site in bacterial cells. Finally, we analyzed the bactericidal activity of the product obtained from an in vitro model of gastrointestinal digestion of the crude extract of these proteins.

\section{MATERIALS AND METHODS}

Ethics Statement. The research described herein was performed on the marine invertebrate $M$. galloprovincialis (Lamarck, 1819), which is not protected by any environmental agency in Italy. This study was conducted in strict accordance with European (Directive 2010/63) and Italian (Decreto Legislativo n. 116/1992) legislation on the care and use of animals for scientific purposes.

Materials and specimens. Chemical reagents were obtained from Sigma, Difco and Diagnostic Pasteur (USA). Electrophoresis reagents and apparatuses were from Biorad. Adult male M. galloprovincialis mussels were kindly provided by the Cooperative Institute for Regional Development and Implementation of mussels (EUROFISH NAPOLI S.R.L.) Baia, in Naples. Whole blood was taken with informed consent from healthy volunteers of Campania University "Luigi Vanvitelli", Naples, Italy, along with the author Rosaria Notariale.

Red Blood Cells and Lymphocytes' purification. Red Blood Cells and Lymphocytes were purified by Ficoll-Paque density gradient centrifugation.
Sperm collection, extraction and purification of M. galloprovincialis PL-proteins. Spermatozoa collection from $M$. galloprovincialis mussels was performed as previously described (Piscopo et al., 2018b). The crude extract containing the three PL-proteins from $M$. galloprovincialis spermatozoa was obtained by extraction with 5\% PCA as previously described (Piscopo et al., 2018c), starting from a pool of spermatozoa collected from 20 Mytilus galloprovincialis specimens. M. galloprovincialis PL-II and PL-III were fractionated by ionic exchange resin cellulose Whatman CM52 as previously described (Vassalli et al., 2015). The lyophilized crude extracts containing the three PL-proteins and the single purified PL-proteins were stored at $-80^{\circ} \mathrm{C}$.

Electrophoretic analyses on polyacrylamide gels of M. galloprovincialis PL-proteins and of their in vitro model of gastrointestinal digestion product. PL-protein samples were analyzed both, by Acetic Acid Urea-Polyacrylamide Gels Electrophoresis (AU-PAGE) and by SDS-PAGE, while the in vitro model of gastrointestinal digestion product of PL-proteins was analyzed only by SDS-PAGE.

AU-PAGE was performed as previously described (Salvati et al., 2008; Piscopo et al., 2018d), using 9.0\% (w/v) acrylamide (acrylamide:bisacrylamide 30:0.8).

SDS-PAGE was performed with stacking gel at 5.0\% (w/v) acrylamide (acrylamide/bis-acrylamide 30:0.15) and separating gel at $18.0 \%(\mathrm{w} / \mathrm{v})$ acrylamide (acrylamide/ bis-acrylamide 30:0.15) as previously described by Piscopo and others (Piscopo et al., 2006).

Microorganisms. Bacterial strains from ATCC (Rockville, MD, USA) were used. They included the following Gram positive bacteria: Staphylococcus aureus (ATCC 13709 and ATCC 6738) and Enterococcus faecalis (ATCC 14428), and Gram negative bacteria: Proteus mirabilis (ATCC 7002), Proteus vulgaris (ATCC 12454), Pseudomonas aeruginosa (ATCC 27853), Salmonella typhi (ATCC 19430), Enterobacter aerogenes (ATCC 13048), Enterobacter cloacae (ATCC 10699), Klebsiella pneumoniae (ATCC 27736), and Escherichia coli (ATCC 8739). Clinical isolates (CI) of almost all of the above bacterial strains were also used to compare their sensitivity to $M$. galloprovincialis PL-proteins. Bacterial clinical isolates were kindly provided by the Plant Pathology Department of the University Federico II, Naples, Italy.

All the bacterial strains from the ATCC and clinical isolate bacteria are shown in Table 1.

Bactericidal activity assays. For the bactericidal activity we tested the crude extract containing all PL-proteins, the purified single molecules (PL-II, PL-III and PL-IV) and the digest, i.e. the product of in vitro model of gastrointestinal digestion of the crude extract of PL-proteins. The crude extract containing all PL-proteins from spermatozoa was obtained by $5 \%$ perchloric acid extraction and is shown in Fig. 1. Bacterial strains were grown on Mueller Hinton $(\mathrm{MH})$ agar plates (DIFCO) and suspended in Mueller Hinton (MH) broth (DIFCO). The minimum inhibitory concentration (MIC) values against bacterial species were performed by broth-dilution method ( $\mathrm{MH}$ broth) as previously described (Basile et al., 1997). The bacterial broth culture was incubated at $37 \pm 1^{\circ} \mathrm{C}$ until it achieved or exceeded the turbidity of the $0.5 \mathrm{McF}$ arland standard (usually two to six h) (Murray et al., 1995; Washington et al., 1972). Next, suspensions containing $10^{6}$ cells $/ \mathrm{mL}$ were prepared by diluting the previous broth culture at 1:100. Ten serial two-fold dilutions were made for the PL-protein concentrations and for the product of in vitro model of gastrointestinal diges- 
tion of the crude extract of these proteins in a range between $0.97-500 \mu \mathrm{g} / \mathrm{mL}$ in $0.05 \mathrm{M}$ Tris buffer ( $\mathrm{pH} 7.4$ ).

For all bacterial strains, a control was made with only bacteria in $\mathrm{MH}$ broth without PL-proteins. MIC and MBC values of the crude extract containing the three PL-proteins, as obtained by extraction with 5\% PCA, and of the purified single molecules (PL-II, PL-III and PL-IV), were determined for all the bacterial strains tested, while MIC and MBC values of the digest were determined only for $S$. aureus (ATCC 6738) and E. coli (ATCC 8739).

The bacterial suspensions were aerobically incubated for $18 \pm 2 \mathrm{~h}$ at $37^{\circ} \mathrm{C}$. The MIC was defined as the lowest concentration able to inhibit any visible bacterial growth. Cultures containing only sterile physiological $0.05 \mathrm{M}$ Tris buffer ( $\mathrm{pH}$ 7.4) which did not influence bacterial growth were used as controls.

The MIC values were also determined for tetracycline hydrochloride (Pharmacia, Milano), benzyl penicillin sodium (Cynamid, Catania) and cefotaxime sodium (Roussel Pharma, Milano) in MH broth using standard methods. Following this, the bacterial cultures were plated on non-inhibitory solid media (Mueller Hinton agar) and incubated at $37 \pm 1^{\circ} \mathrm{C}$ for $18 \pm 2 \mathrm{~h}$ to detect survival. MBC was then estimated as the lowest concentration of bactericidal molecule resulting in no growth. Each experiment was repeated three times.

Fluorescence microscopy. $5 \mathrm{mg} / \mathrm{mL}$ of the crude extract containing all PL-proteins in $100 \mathrm{mM}$ HEPES $(\mathrm{pH} 7.4)$ were incubated with 7-diethylamino coumarin-3-carboxylic acid, succinimidyl ester (DEAC,SE Anaspec) at 1:3 molar ratio (PL-proteins: DEAC,SE) at room temperature for $24 \mathrm{~h}$. DEAC,SE -PL-protein conjugate was added both to $S$. aureus (ATCC 6738) and

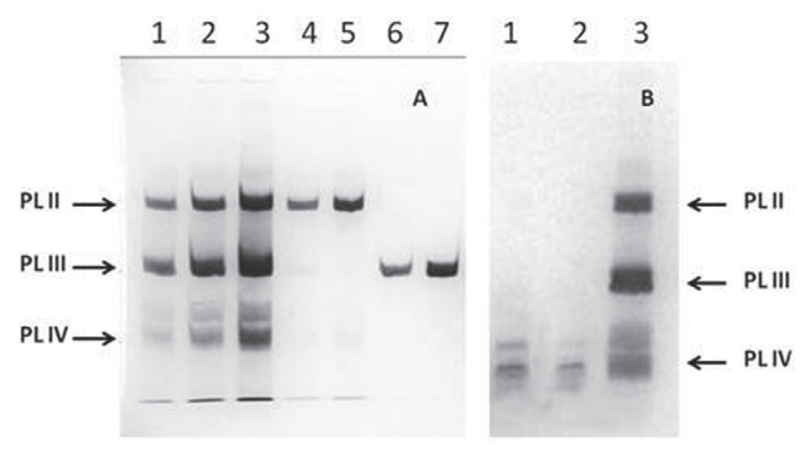

Figure 1. Analysis of PL-proteins from M. galloprovincialis

(A) lanes 1, 2, and 3 (crude extract containing PL-proteins, 5, 10 and $20 \mu \mathrm{g}$, respectively); lanes 4,5 (PL-II, 5 and $10 \mu \mathrm{g}$ respectively), lanes 6 and 7 (PL-III, 5 and $10 \mu \mathrm{g}$ respectively). (B) lanes 1 and 2 (PL-IV, 6 and $3 \mu \mathrm{g}$ respectively), lane 3 (crude extract containing PL-proteins, $10 \mu \mathrm{g}$ )

E. coli (ATCC 8739), inoculated at a sub lethal concentration (15 and $31.3 \mu \mathrm{g} / \mathrm{mL}$, respectively), and incubated for $24 \mathrm{~h}$ at $37^{\circ} \mathrm{C}$. Then, the cells were washed with culture medium to remove excess dyes and mounted on a glass slide. DEAC,SE-free dye was added both to $S$. aureus (ATCC 6738) and E. coli (ATCC 8739) inocula as a negative control. Bacteria were also stained with 4',6-diamino-2-phenylindole (DAPI) in order to stain bacterial DNA. Images of the bacterial cells were obtained with a Nikon Eclipse E1000 microscope (Nikon Instruments Europe, Tokyo, Japan) with a magnification of 400x.

Measurement of nucleotide leakage. Nucleotide leakage from S. aureus (ATCC 6738) and E. coli (ATCC 8739) was determined as follows: logarithmic phase bac-

Table 1. Evaluation of bacteriostatic activity of M. galloprovincialis PL-proteins

\begin{tabular}{|c|c|c|c|c|c|c|c|c|}
\hline & & $\begin{array}{l}\mathrm{MIC} \\
\mu \mathrm{g} / \mathrm{mL}\end{array}$ & $\begin{array}{l}\mathrm{MIC} \\
\mu \mathrm{g} / \mathrm{mL}\end{array}$ & $\begin{array}{l}\mathrm{MIC} \\
\mu \mathrm{g} / \mathrm{mL}\end{array}$ & $\begin{array}{l}\mathrm{MIC} \\
\mu \mathrm{g} / \mathrm{mL}\end{array}$ & $\begin{array}{l}\mathrm{MIC} \\
\mu \mathrm{g} / \mathrm{mL}\end{array}$ & $\begin{array}{l}\mathrm{MIC} \\
\mu \mathrm{g} / \mathrm{mL}\end{array}$ & $\begin{array}{l}\mathrm{MIC} \\
\mu \mathrm{g} / \mathrm{mL}\end{array}$ \\
\hline Gram reaction & Bacterial strains & Crude extract & PLII & PLIII & PIV & CTAX & PENG & TET \\
\hline+ & S. aureus ATCC 6738 & $31.3 \pm 0.0$ & $31.3 \pm 0.2$ & $62.5 \pm 0.5$ & $125 \pm 0.5$ & $2 \pm 0.1$ & $0.3 \pm 0.1$ & $2 \pm 0.1$ \\
\hline+ & S. aureus ATCC 13709 & $15.7 \pm 0.3$ & $15.7 \pm 0.1$ & $31.3 \pm 0.1$ & $31.3 \pm 0.2$ & $2 \pm 0.1$ & $0.03 \pm 0$ & $2 \pm 0.1$ \\
\hline+ & S. aureus $\mathrm{Cl}$ & $31.3 \pm 0.2$ & $31.3 \pm 0.2$ & $62.5 \pm 0.3$ & $31.3 \pm 0.2$ & $\mathrm{R}$ & $\mathrm{R}$ & $\mathrm{R}$ \\
\hline+ & E. faecalis ATCC 14428 & $31.3 \pm 0.1$ & $62.5 \pm 0.5$ & $62.5 \pm 0.1$ & $62.5 \pm 0.5$ & $\mathrm{R}$ & $8 \pm 0.2$ & $2 \pm 0.1$ \\
\hline+ & E. faecalis $\mathrm{Cl}$ & $62.5 \pm 0.5$ & $62.5 \pm 0.3$ & $125 \pm 0.5$ & $125 \pm 0.3$ & $\mathrm{R}$ & $\mathrm{R}$ & $\mathrm{R}$ \\
\hline- & P. vulgaris ATCC 12454 & $31.3 \pm 0.1$ & $62.5 \pm 0.5$ & $125 \pm 0.5$ & $125 \pm 0.3$ & $2 \pm 0.1$ & $4 \pm .3$ & $\mathrm{R}$ \\
\hline- & P. vulgaris $\mathrm{Cl}$ & $62.5 \pm 0.1$ & $62.5 \pm 0.2$ & $125 \pm 0.3$ & $250 \pm 0.5$ & $32 \pm 0.3$ & $\mathrm{R}$ & $\mathrm{R}$ \\
\hline- & P. mirabilis ATCC 7002 & $250 \pm 0.2$ & $31.3 \pm 0.3$ & $62.5 \pm 0.2$ & $62.5 \pm 0.3$ & $0.03 \pm 0$ & $4 \pm 0.2$ & $32 \pm 0.6$ \\
\hline- & S. typhi ATCC 19430 & $7.8 \pm 0.1$ & $15.7 \pm 0.2$ & $31.3 \pm 0.2$ & $31.3 \pm 0.1$ & $0.5 \pm 0.1$ & $4 \pm 0.2$ & $1 \pm 0.3$ \\
\hline- & S. typhi Cl & $7.8 \pm 0.1$ & $15.7 \pm 0.1$ & $62.5 \pm 0.5$ & $31.3 \pm 0.1$ & $1 \pm 0.1$ & $2 \pm 0.1$ & $1 \pm 0.1$ \\
\hline- & E. cloacae ATCC 10699 & $15.7 \pm 0.3$ & $31.3 \pm 0.1$ & $62.5 \pm 0.1$ & $62.5 \pm 0.2$ & $\mathrm{R}$ & $4 \pm 0.4$ & $\mathrm{R}$ \\
\hline- & E. cloacae Cl & $31.3 \pm 0,2$ & $31.3 \pm 0.1$ & $125 \pm 0.4$ & $125 \pm 0.1$ & $\mathrm{R}$ & $\mathrm{R}$ & $\mathrm{R}$ \\
\hline- & E. aerogenes ATCC 13048 & $125 \pm 0.3$ & $62.5 \pm 0.5$ & $125 \pm 0.4$ & $125 \pm 0.2$ & $\mathrm{R}$ & $4 \pm 0.1$ & $\mathrm{R}$ \\
\hline- & E. aerogenes $\mathrm{Cl}$ & $250 \pm 0.1$ & $125 \pm 0.5$ & $125 \pm 0.5$ & $250 \pm 0.5$ & $\mathrm{R}$ & $\mathrm{R}$ & $\mathrm{R}$ \\
\hline- & P. aeruginosa ATCC 27853 & $31.3 \pm 0.1$ & $62.5 \pm 0.3$ & $125 \pm 0.5$ & $125 \pm 0.3$ & $16 \pm 0.3$ & $\mathrm{R}$ & $32 \pm 0.1$ \\
\hline- & P. aeruginosa $\mathrm{Cl}$ & $62.5 \pm 0.5$ & $125 \pm 0.3$ & $250 \pm 0.5$ & $125 \pm 0.4$ & $32 \pm 0.4$ & $\mathrm{R}$ & $\mathrm{R}$ \\
\hline- & E. coli ATCC 8739 & $62.5 \pm 0.3$ & $62.5 \pm 0.1$ & $62.5 \pm 0.3$ & $125 \pm 0.3$ & $4 \pm 0.1$ & $2 \pm 0.1$ & $8 \pm 0.1$ \\
\hline
\end{tabular}

Minimum Inhibitory Concentration (MIC) values $(\mu \mathrm{g} / \mathrm{mL}$ ) of the crude extract containing the three M. galloprovincialis PL-proteins and those of the purified PL-II, PL-III, and PL-IV for bacterial strains analyzed. CTAX, Cefotaxime; PENG, Benzyl Penicillin Sodium; TET, Tetracycline; Cl, Clinically Isolated. R, Resistant. Values represent mean \pm S.D. $(n=3)$. 
terial cells were diluted in $\mathrm{MH}$ to make $1 \times 10^{6} \mathrm{CFU} /$ $\mathrm{mL}$. Then, $1 \mathrm{~mL}$ of the suspensions were incubated with three concentrations of crude extract containing all PL-proteins $(1 / 2 \times \mathrm{MIC}, 1 \times \mathrm{MIC}, 2 \times \mathrm{MIC})$ at $37^{\circ} \mathrm{C}$ for 1 $\mathrm{h}$ and then filtered through a $0.22 \mu \mathrm{m}$ filter membrane. As a positive control we used $3.4 \mathrm{mM}$ EDTA. Filtrate absorbance at $260 \mathrm{~nm}$ was measured by Thermo Helios Omega UV-Vis Spectrophotometer.

DNA and RNA extraction from $\boldsymbol{E}$. coli. DNA extraction: from an overnight liquid culture of $100 \mathrm{~mL}$ E. coli (ATCC 8739) in MH, the bacterial cells were collected by centrifugation for 2 minutes at $14000 \times \mathrm{g}$ at $4^{\circ} \mathrm{C}$. The cells were suspended in $1 \mathrm{~mL}$ of lysis solution (10 mM Tris- $\mathrm{HCl} \mathrm{pH} 8,100 \mathrm{mM} \mathrm{NaCl}, 2 \% \mathrm{SDS}, 10 \mathrm{mM}$ EDTA $\mathrm{pH} 8,20 \mu \mathrm{g} / \mathrm{mL}$ Proteinase $\mathrm{K}$ ) and incubated for 30 minutes at $56^{\circ} \mathrm{C}$. The DNA was purified by phenol-chloroform extraction. At the end, the sample was resuspended in $\mathrm{ddH}_{2} \mathrm{O}$ and quantified using Nanodrop (NanoDrop 1000 ThermoScientific).

RNA extraction: SV Total RNA Isolation System (Promega) was used for RNA extraction from E. coli (ATCC 8739) following the manufacturer's protocol for Gram-negative bacteria.

Analysis of the effect of $M$. galloprovincialis PL-proteins on $E$. coli DNA and RNA electrophoretic mobility. The effect of $M$. galloprovincialis PL-proteins on E. coli DNA and RNA was evaluated by Electrophoretic Mobility Shift Assay (EMSA and REMSA respectively) on $1 \%$ and $1.5 \%$ agarose gels, respectively, using $300 \mathrm{ng}$ of the specific nucleic acid and increasing amounts of crude extract containing all PL-proteins, expressed as protein/nucleic acid w/w ratios. M. galloprovincialis PL-proteins were added to $300 \mathrm{ng}$ of E. coli DNA or RNA in a final volume of $20 \mu \mathrm{L}$ containing $1 x$ TBE. After incubation for 10 minutes at room temperature, each mixture was analyzed on an agarose gel in TBE, as described by Carbone and others (Carbone et al., 2012). DNA or RNA migration was visualized by staining slab gels with ethidium bromide $(2 \mu \mathrm{g} / \mathrm{mL})$ after electrophoresis. Protein to DNA ratios (w/w) are indicated on the wells of the gels.

Red blood cell lysis assay. The effects of Mytilus galloprovincialis crude extract containing PL-proteins was analyzed on isolated human red blood cells (RBCs) to evaluate their toxicity. We placed $1 \times 10^{6}$ erythrocytes in $500 \mu \mathrm{L}$ of $150 \mathrm{mM} \mathrm{NaCl}$ containing proteins at different concentrations that have shown bactericidal activity, in order to evaluate the possible RBC lysis. We prepared two control samples: one with $1 \times 10^{6}$ erythrocytes in $500 \mu \mathrm{L}$ of physiological solution (ctr) containing 150 $\mathrm{mM} \mathrm{NaCl}$ without PL-proteins and the other with $1 \times 10^{6}$ erythrocytes in $500 \mu \mathrm{L}$ of distilled water, without PLproteins, which was used to obtain total RBCs lysis. The erythrocytes were incubated with PL-proteins for $24 \mathrm{~h}$ at $4^{\circ} \mathrm{C}$ and the assay was performed in triplicate. The lysis of RBCs was monitored by the release of hemoglobin. After removing the intact RBCs by centrifugation, we determined the spectrophotometric hemoglobin $(\mathrm{Hb})$ absorbance at $415 \mathrm{~nm}$, contained in the supernatant, and we obtained the number of lysed RBCs considering $\mathrm{Hb}$ $\varepsilon \mathrm{mM}=131$ at this wavelength and that one RBC contains about 32 picograms of $\mathrm{Hb}$. The percentage of lysed RBCs after treatment with different amounts of PL-proteins was obtained by the ratio between the values of absorbance at $415 \mathrm{~nm}$ of PL-proteins treated and that in which total lysis occurred with $\mathrm{dH}_{2} \mathrm{O}$ which was indicated as $100 \%$.

Cell viability assay. The cytotoxicity of crude extract containing PL-proteins on human lymphocytes was measured using the 3-(4,5-dimethylthiazol-2yl)-2,5-diphenyl tetrazolium bromide (MT'T) assay in agreement with the manufacturer's instructions (MT'T Cell Viability Assay Kit; Biotum, Inc) (Liu et al., 1997). Cells $\left(1 \times 10^{6}\right.$ cells/well) in $420 \mu \mathrm{L}$ of RPMI 1640 were seeded into two 24 -well microtiter plates at $37^{\circ} \mathrm{C}$ and treated with PL-proteins $(15.7-250 \mu \mathrm{g} / \mathrm{mL})$ for $24 \mathrm{~h}$. At the end of the exposure, $40 \mu \mathrm{L}$ of $5 \mathrm{mg} / \mathrm{mL}$ MTT was added to each well and incubated for $2 \mathrm{~h}$ at $37^{\circ} \mathrm{C}$, and then the water-insoluble formazan blue crystals generated were dissolved in $500 \mu \mathrm{L}$ of dimethylsulfoxide (DMSO; Sigma-Aldrich, Saint Quentin Fallavier, France) by pipetting up and down several times and shaking for $15 \mathrm{~min}$ on an orbital shaker at $20^{\circ} \mathrm{C}$. The samples were read at $570 \mathrm{~nm}$ and $630 \mathrm{~nm}$ (background) to obtain cell viability $\%$ (optical density, $\mathrm{OD}_{570}-\mathrm{OD}_{630}$ ). The percentage of cell viability was calculated by the following formula: [OD $(570 \mathrm{~nm})-\mathrm{OD}(630 \mathrm{~nm})$ treated/ OD(570 nm) $\mathrm{OD}(630 \mathrm{~nm})$ untreated] $\times 100 \%$ (Oliveira et al., 2013). All experiments were performed in triplicate, and the relative cell viability $(\%)$ was expressed as a percentage relative to the untreated control cells (ctr), i.e. cells treated with RPMI 1640 medium only. The cell proliferation of ctr was indicated as $100 \%$.

In vitro model of gastrointestinal digestion of the crude extract of PL-proteins. The assay was performed according to the procedure described in (Raiola et al., 2012) with slight modification. GI digestion was distinguished into salivary, gastric and duodenal digestive steps. For the salivary digestion, the extract samples (20 $\mathrm{mg}$ ) were mixed with $6 \mathrm{~mL}$ of artificial saliva composed of: $\mathrm{KCl}(89.6 \mathrm{~g} / \mathrm{L}), \mathrm{KSCN}(20 \mathrm{~g} / \mathrm{L}), \mathrm{NaH}_{2} \mathrm{PO}_{4}(88.8$ g/L), $\mathrm{Na}_{2} \mathrm{SO}_{4}(57.0 \mathrm{~g} / \mathrm{L}), \mathrm{NaCl}(175.3 \mathrm{~g} / \mathrm{L}), \mathrm{NaHCO}_{3}$ $(84.7 \mathrm{~g} / \mathrm{L})$, urea $(25.0 \mathrm{~g} / \mathrm{L})$ and $290 \mathrm{mg}$ of $\alpha$-amylase. The $\mathrm{pH}$ of the solution was adjusted to 6.8 with $0.1 \mathrm{~N}$ $\mathrm{HCl}$. The mixture was introduced in a plastic bag containing $40 \mathrm{~mL}$ of water and homogenized in a Stomacher 80 Microbiomaster (Seward, Worthing, UK) for 3 min. Immediately, $0.5 \mathrm{~g}$ of pepsin (14800 U) dissolved in $0.1 \mathrm{~N} \mathrm{HCl}$ was added, the $\mathrm{pH}$ was adjusted to 2.0 with $6 \mathrm{~N} \mathrm{HCl}$, and then incubated at $37^{\circ} \mathrm{C}$ in a Polymax 1040 orbital shaker (250 rpm) (Heidolph, Schwabach, Germany) for $2 \mathrm{~h}$. After the gastric digestion, the pancreatic digestion was simulated as follows: the $\mathrm{pH}$ was increased to 6.5 with $0.5 \mathrm{~N} \mathrm{NaHCO}$ and then $5 \mathrm{~mL}$ of a mixture of pancreatin $(8.0 \mathrm{mg} / \mathrm{mL})$ and bile salts $(50.0 \mathrm{mg} / \mathrm{mL})(1: 1 ; \mathrm{v} / \mathrm{v})$ dissolved in $20 \mathrm{~mL}$ of water was added and incubated at $37^{\circ} \mathrm{C}$ in an orbital shaker (250 rpm) for $2 \mathrm{~h}$. The intestinal digest was freeze-dried and then extracted with acetonitrile:water $(84: 16 ; \mathrm{v} / \mathrm{v})$ mixture. The supernatant was evaporated to dryness and then stored at $-20^{\circ} \mathrm{C}$.

Statistical analysis. Multiple group data were analyzed using one-way ANOVA. The Student's t-test was used to compare means between the groups. Values were considered significant when $p<0.05$. Statistically significant differences are defined at the 95\% confidence interval. Data are shown as mean \pm S.D.

\section{RESULTS}

\section{Isolation and analysis of PL-proteins from M. galloprovincialis}

Before evaluation of the bactericidal activity, both crude extract and the single purified PL-proteins of $M$ galloprovincialis were analyzed by AU-PAGE. 
Table 2. Evaluation of bactericidal activity of M. galloprovincialis PL-proteins

\begin{tabular}{|c|c|c|c|c|}
\hline & $\mathrm{MBC} \mu \mathrm{g} / \mathrm{mL}$ & $\mathrm{MBC} \mu \mathrm{g} / \mathrm{mL}$ & $\mathrm{MBC} \mu \mathrm{g} / \mathrm{mL}$ & $\mathrm{MBC} \mu \mathrm{g} / \mathrm{mL}$ \\
\hline Bacterial strains & CRUDE EXTRACT & PLII & PLIII & PIV \\
\hline S. aureus ATCC 6738 & $62.5 \pm 0.2$ & $62.5 \pm 0.2$ & $125 \pm 0.4$ & $250 \pm 0.5$ \\
\hline S. aureus ATCC 13709 & $31.3 \pm 0.1$ & $31.3 \pm 0.1$ & $62.5 \pm 0.2$ & $62.5 \pm 0.3$ \\
\hline S. aureus $\mathrm{Cl}$ & $62.5 \pm 0.3$ & $62.5 \pm 0.2$ & $62.5 \pm 0.3$ & $125 \pm 0.4$ \\
\hline E. faecalis ATCC 14428 & $62.5 \pm 0.2$ & $125 \pm 0.3$ & $125 \pm 0.3$ & $125 \pm 0.4$ \\
\hline E. faecalis $\mathrm{Cl}$ & $125 \pm 0.3$ & $125 \pm 0.4$ & $250 \pm 0.5$ & $250 \pm 0.5$ \\
\hline P. vulgaris ATCC 12454 & $62.5 \pm 0.3$ & $62.5 \pm 0.3$ & $125 \pm 0.5$ & $125 \pm 0.5$ \\
\hline P. vulgaris $\mathrm{Cl}$ & $125 \pm 0.5$ & $250 \pm 0.5$ & $250 \pm 0.4$ & $250 \pm 0.3$ \\
\hline P. mirabilis ATCC 7002 & $250 \pm 0.5$ & $62.5 \pm 0.3$ & $125 \pm 0.5$ & $125 \pm 0.3$ \\
\hline S. typhi ATCC 19430 & $15.7 \pm 0.2$ & $15.7 \pm 0.2$ & $62.5 \pm 0.3$ & $62.5 \pm 0.2$ \\
\hline S. typhi Cl & $31.3 \pm 0.2$ & $31.3 \pm 0.3$ & $62.5 \pm 0.3$ & $125 \pm 0.4$ \\
\hline E. cloacae ATCC 10699 & $31.3 \pm 0.1$ & $31.3 \pm 0.1$ & $125 \pm 0.3$ & $125 \pm 0.3$ \\
\hline E. cloacae $\mathrm{Cl}$ & $62.5 \pm 0.3$ & $62.5 \pm 0.3$ & $250 \pm 0.5$ & $250 \pm 0.5$ \\
\hline E. aerogenes ATCC 13048 & $250 \pm 0.5$ & $250 \pm 0.5$ & $250 \pm 0.5$ & $250 \pm 0.5$ \\
\hline E. aerogenes $\mathrm{Cl}$ & $250 \pm 0.5$ & $250 \pm 0.5$ & $250 \pm 0.4$ & $250 \pm 0.4$ \\
\hline P. aeruginosa ATCC 27853 & $31.3 \pm 0.2$ & $62.5 \pm 0.3$ & $250 \pm 0.4$ & $250 \pm 0.4$ \\
\hline P. aeruginosa $\mathrm{Cl}$ & $125 \pm 0.4$ & $250 \pm 0.5$ & $250 \pm 0.5$ & $250 \pm 0.5$ \\
\hline E. coli ATCC 8739 & $125 \pm 0.4$ & $125 \pm 0.4$ & $125 \pm 0.4$ & $250 \pm 0.4$ \\
\hline
\end{tabular}

Minimum Bactericidal Concentration $(\mathrm{MBC})$ values $(\mu \mathrm{g} / \mathrm{mL})$ of the crude extract containing the three PL-proteins and those of the purified PL-ll, PLIII, and PL-IV for bacterial strains analyzed. Cl, Clinically Isolated. Values represent mean \pm S.D. $(n=3)$.

Individually purified PL-II and PL-III are shown in Fig. 1A, while PL-IV in Fig. 1B in comparison with the crude extract which contained the three $M$. galloprovincialis PL-proteins. The percentage of PL-proteins evaluated of the overall nuclear proteins is in accordance with those shown by Lewis and Ausió (Lewis \& Ausió, 2002).

\section{Evaluation of bactericidal activity of $M$. galloprovincialis PL-proteins}

Both the crude extract, as well as the individually purified PL-proteins of $M$. galloprovincialis, were tested

A

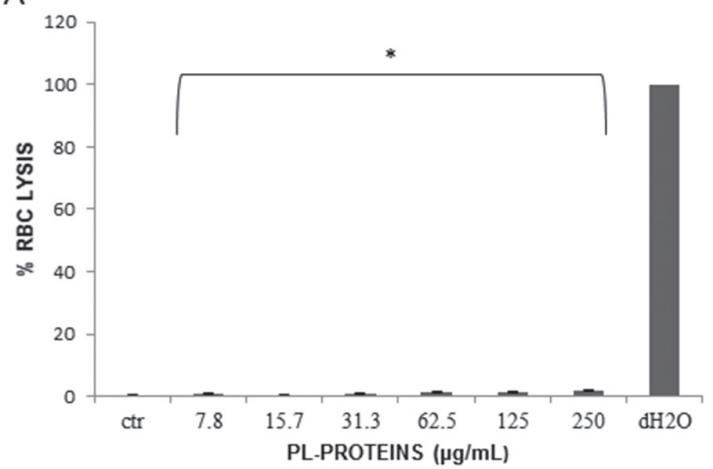

for evaluation of their bactericidal activity. For this aim, MIC and MBC assays on Gram-positive and Gram-negative bacteria and on clinical isolates (CIs) of some bacterial strains were performed. All bacteria strains were inhibited by the tested molecules, with different MIC values as shown in Table 1. PLproteins had MIC values ranging from 7.8 to $250 \mu \mathrm{g} /$ $\mathrm{mL}$. In order to investigate if these molecules could not only inhibit bacterial growth but also induce bacterial death, the cultures were plated on non-inhibitory solid media and incubated for $24 \mathrm{~h}$ to evaluate the MBC values. All molecules showed bactericidal effects

\section{B}

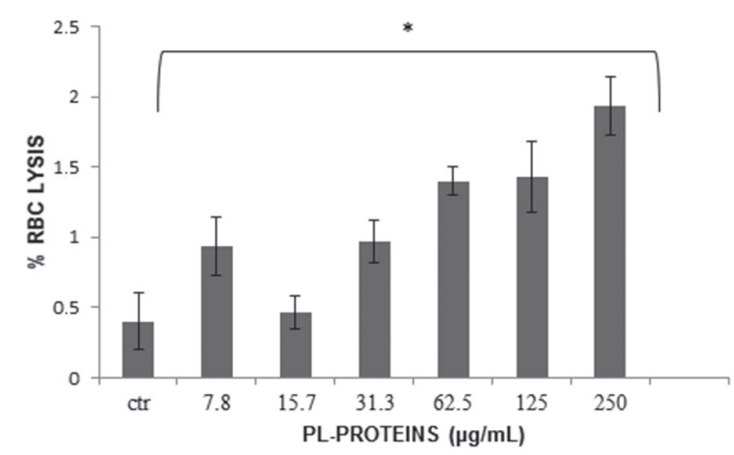

Figure 2. Impact of PL-proteins on RBCs lysis

(A) the percent human RBCs lysed after treatment. The histogram annotated with $\mathrm{dH}_{2} \mathrm{O}$ represents the total lysis (100\%) of RBCs obtained by placing RBCs in distilled water, while the other histograms represent the percentage of lysed cells in physiological solution alone (ctr) and in this solution with the addition of increasing amounts of PL-proteins expressed as $\mu \mathrm{g} / \mathrm{mL}$. (B) the same results as in A without the histogram relative to total lysis for better data visualization. Values represent mean \pm S.D. $(n=3)$. Asterisk indicates a statistically significant difference $(P<0.05)$ when compared to control. 


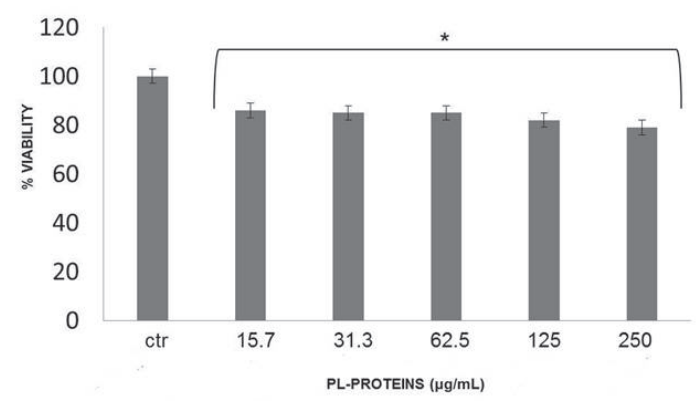

Figure 3. Impact of PL-proteins on cell viability.

Percent human lymphocyte viability after treatment with PL-proteins by MTT assays. ctr refers to control cells that were only treated with the RPMI 1640 medium and their \% viability was indicated as 100 . Values represent mean \pm S.D. $(n=3)$. Asterisk indicates a statistically significant difference $(P<0.05)$ when compared to control.

with MBC values ranging from 15.7 to $250 \mu \mathrm{g} / \mathrm{mL}$, as shown in Table 2, and were active against Gram-positive and Gram-negative species. The most sensitive bacterial strains were found to be Salmonella typhi and its CI, Staphylococcus aureus (ATCC 13709) and Enterobacter cloacae (ATCC 10699). The less sensitive bacteria strains were Proteus mirabilis (ATCC 7002) and Enterobacter aerogenes (ATCC 13048). Generally, CIs proved to be more resistant to PL-proteins than their standard strain counterparts.

\section{Impact of PL-proteins on viability of human cells}

In order to assess the impact of PL-proteins on viability of human cells, we performed RBC lysis and MT'T assays. The results show that, in the presence of all PL-protein concentrations, the percentage of lysed cells is much lower than that obtained in distilled water (indicated as 100\%) and is not much higher with respect to that obtained in the presence of physiological solution alone (ctr). In particular, the maximum percentage of lysed cells after incubation with PL-proteins was about 2, as shown in Fig. 2B.

MT'T assays performed on lymphocytes treated for $24 \mathrm{~h}$ with the same amounts of crude extract containing PL-proteins indicated that cell viability was at least 80-90\% (Fig. 3).

\section{Localization of PL-proteins in bacterial cells}

The purpose of this section is to establish the action site of PL-proteins in the bacterial cell. To achieve this goal, we performed fluorescence microscopy observations using DEAC,SE -PL-protein con-

A

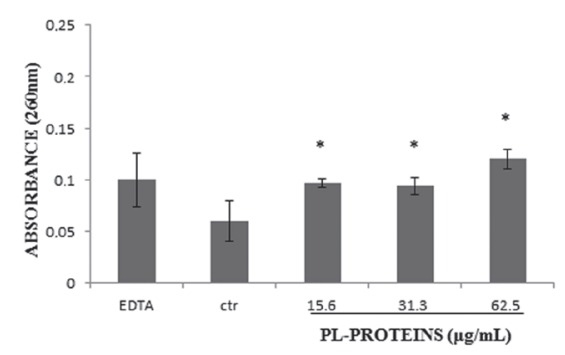

A

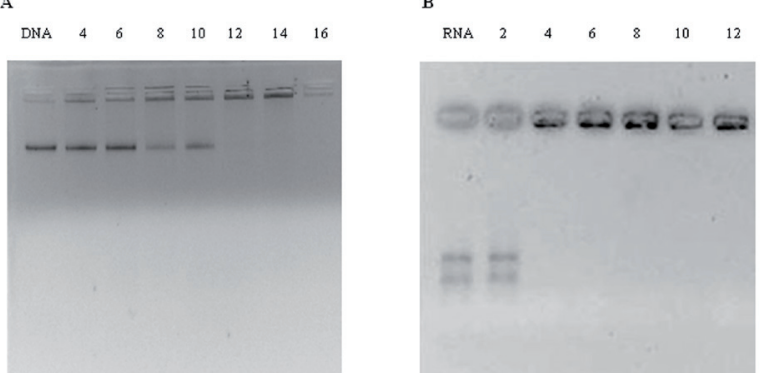

Figure 5. Analysis of the effect of M. galloprovincialis PL-proteins' binding on $E$. coli nucleic acids' mobility

EMSA (A) and REMSA (B) analyzed on $1 \%$ and $1.5 \%$ agarose gels, respectively, performed with E. coli (ATCC 8739) DNA(A) and RNA (B), and increasing amounts of M. galloprovincialis PL-proteins. The numbers indicated on the wells indicate the PL-proteins/nucleic acid $(\mathrm{w} / \mathrm{w})$ ratios. The samples indicated with DNA and RNA correspond to the nucleic acid alone.

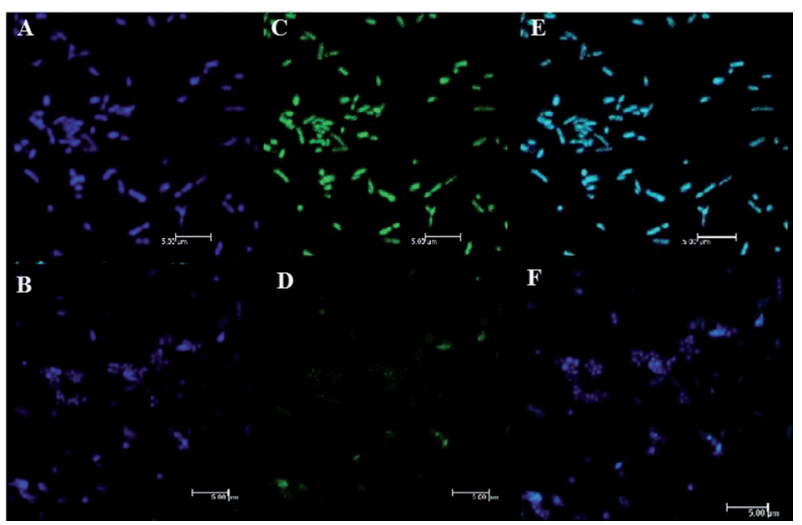

Figure 4. Localization of PL-proteins in bacterial cells.

Fluorescence microscopic observation of E. coli (ATCC 8739) (C) and S. aureus (ATCC 6738) (D) cells treated with DEAC,SEPL-protein conjugate. Panels A and B show E. coli (ATCC 8739) and S. aureus (ATCC 6738) cells, respectively, stained with DAPI. Merged image of DEAC,SE and DAPI-stained E. coli (ATCC 8739) (E) and S. aureus (ATCC 6738) (F) cells. Magnification: 400x; scale bars, $5 \mu \mathrm{m}$.

jugate. The result showed that DEAC,SE-PL-protein conjugates added both, to $S$. aureus (ATCC 6738) and E. coli (ATCC 8739) inocula at a sub lethal concentration, produced a uniform distribution of fluorescence on the cell surface and even inside the cell (Figs. 4D and $C$, respectively). In fact, the images appeared similar to the results obtained by staining the same bacteria with DAPI which enters cells and binds DNA (Figs. 4B and A, respectively). Experiments performed
B

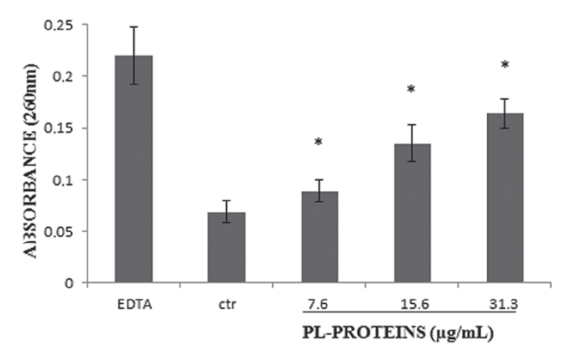

Figure 6. Cell nucleotide leakage induced by PL-proteins

Cell nucleotide leakage by treating E. coli (ATCC 8739) (A) and S. aureus (ATCC 6738) (B) with PL-proteins. EDTA was used as a positive control. Data are expressed as mean \pm S.D. Asterisk indicates a statistically significant difference $(P<0.05)$ when compared to control. 


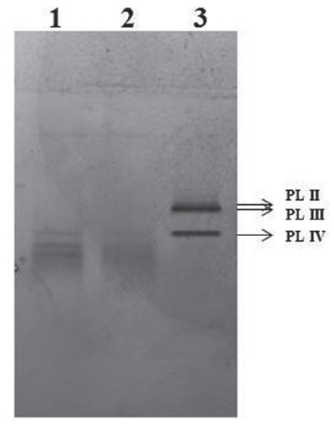

Figure 7. Analysis of the product of in vitro model of gastrointestinal digestion of $M$. galloprovincialis PL-proteins

Lanes 1 and 2: (digest, 20 and $10 \mu \mathrm{g}$, respectively) analyzed by SDS-PAGE in comparison with the undigested PL-proteins (lane 3)

with DEAC,SE-free dye (non-conjugated), used as controls (data not shown), indicate that the dye was not taken up by the cells in the absence of PL-proteins. Merged images are also shown of DEAC,SE and DAPI stained E. coli (ATCC 8739) (Fig. 4E) and S. aureus (ATCC 6738) (Fig. 4F).

\section{Analysis of the effect of M. galloprovincialis PL-proteins binding on $E$. coli nucleic acids mobility}

To evaluate the possible interaction of PL-proteins with some internal cellular targets, such as bacterial nucleic acids, we tested PL-proteins in EMSA and REMSA experiments using E. coli (ATCC 8739) DNA and RNA, respectively. The results suggested that PLproteins have affinity for both bacterial nucleic acids. In fact, the saturation of nucleic acids, i.e. when all the nucleic acid bands are observed near the origin of migration, is achieved at a PL/nucleic acid ratio 4 for RNA and 12 in the case of DNA (Fig. 5).

\section{Nucleotide leakage induced by PL-proteins}

In order to also investigate the possibility of action of PL-proteins at a membrane level, we performed experiments to check the nucleotide leakage from bacterial cells after treatment with the same PL-protein amounts which have shown bactericidal effects. The experiments were conducted on $S$. aureus (ATCC 6738) and E. coli (ATCC 8739) using $3.4 \mathrm{mM}$ EDTA as a positive control. The results demonstrated that there was nucleotide leakage, particularly from $S$. aureus cells (Fig. 6).

\section{Analysis and bactericidal activity of the in vitro gastrointestinal digestion product of PL-proteins}

To assess whether bactericidal activity of PL-proteins was maintained even after gastrointestinal diges- tion, we performed the in vitro model of gastrointestinal digestion of PL-proteins; analyzed the digest by SDS-PAGE and determined MIC and MBC values for S. aureus (ATCC 6738) and E. coli (ATCC 8739). SDSPAGE analysis shows that the digest resulted in PLIV plus a mixture of peptides. The digest, compared to the undigested PL-proteins, presents the same bactericidal activity against Staphylococcus aureus but lower activity against Escherichia coli, as shown by MIC and MBC values (Table 3).

\section{DISCUSSION}

The growing number of bacteria resistant to conventional antibiotics has become a grave medical problem that has generated extensive interest in the use of 'natural' alternatives. Although terrestrial biodiversity has been the base of the pharmaceutical industry, the oceans have colossal biodiversity and potential to provide novel compounds with commercial value (Smit, 2004; El-Gamal et al., 2013). This is because marine invertebrates, living within very difficult, competitive, and hostile surroundings represent a great reservoir for compounds with improved bactericidal activity. Mytilus galloprovincialis is an excellent bioindicator and bioaccumulator of marine pollution (Piscopo et al., 2016) and as we have recently shown, it has altered levels of hsp70 in spermatozoa, gonadal and gill tissues (Piscopo et al., 2018c; Piscopo et al., 2017) and demonstrates changes in sperm protaminelike protein properties (Piscopo et al., 2018b, Piscopo et al., 2018c), as a response to environmental stress/geographical site of this organism. The first work concerning bactericidal activity identified in mollusks was relative to the mucus of the giant snail Achatina fulica (Kubota et al., 1985). Afterwards, bacteriostatic proteins were also discovered in the sea hares Aplysia kurodai and Dolabella auricularia (Kamiya et al., 1986; Ijijma et al., 2003) and in 1996, true antimicrobial peptides were isolated from M. galloprovincialis (Hubert et al., 1996) and M. edulis (Charlet et al., 1996). Given that nothing has been shown in the literature about the bactericidal activity of PL-proteins, which are sperm proteins that are different from the histone $(\mathrm{H})$ and protamine $(\mathrm{P})$ types, we investigated the bactericidal activity of $M$. galloprovincialis PL-proteins. The primary structure of the Mytilus PL-proteins is shown in Carlos and others (Carlos et al., 1993a) and in Rocchini and others (Rocchini et al., 1995).

PL-proteins were extracted from spermatozoa, purified and analyzed by AU-PAGE.

PL-II and PL-III appeared as a highly pure single band (Fig. 1A lanes 4 and 5 and Fig. $1 \mathrm{~A}$ lanes 6 and 7 , respectively). In contrast, several subcomponents were present in the region of the gel corresponding to PL-IV (Fig. 1B lanes 1 and 2) and reflect the microheteroge-

Table 3. Evaluation of bacteriostatic and bactericidal activities of the product obtained from in vitro model of gastrointestinal digestion of protamine-like proteins

\begin{tabular}{lllll}
\hline & MIC & MBC & MIC & MBC \\
\hline Bacterial strains & DIGEST & DIGEST & CRUDE EXTRACT & CRUDE EXTRACT \\
\hline S. aureus ATCC 6738 & $31.3 \pm 0.2$ & $62.5 \pm 0.2$ & $31.3 \pm 0.0$ & $62.5 \pm 0.2$ \\
\hline E. coli ATCC 8739 & $125 \pm 0.3$ & $250 \pm 0.5$ & $62.5 \pm 0.3$ & $125 \pm 0.4$ \\
\hline
\end{tabular}

Comparison between MIC and MBC values $(\mu \mathrm{g} / \mathrm{mL})$ of the digest and the crude extract containing the three $M$. galloprovincialis $\mathrm{PL}$-proteins obtained for Gram-positive, Staphylococcus aureus (ATCC 6738) and Gram-negative E. coli (ATCC 8739) bacteria. MIC and MBC values ( $\mu$ g/mL) represent mean \pm S.D. $(n=3)$. 
neity of this protein, as previously described by Ausió and Subirana (Ausió \& Subirana, 1982), similar to what is observed in protamines (Ausió et al., 1989). Such microhereterogeneity in PL-IV is also due to the fact that $8 \%$ of its serines are phosphorylated (Ausió \& Subirana, 1982). Both, the crude extract containing the three PL-proteins and the singularly purified PL-II, PL-III and PL-IV were used to test their bactericidal activity against several Gram-positive and Gram-negative bacteria. Both, the crude extract and the individual PL-proteins, yielded bactericidal activity against all the strains tested. The MBC values for almost all bacterial strains showed that the crude extract containing the three PL-proteins was more efficient for only 4 out of 16 strains, and particularly for Enterococcus faecalis (ATCC 14428), Proteus vulgaris (CI), and Pseudomonas aeruginosa (ATCC 27853) and its CI. The MBC of crude extract was found to have an efficiency similar to PL-II for 8 out of 16 tested strains and particularly in Staphylococcus aureus (ATCC 13709 and ATCC 6738), Enterococcus faecalis (CI), Proteus vulgaris (ATCC 12454), Salmonella typhi (ATCC 19430) and its CI, and Enterobacter cloacae (ATCC 10699) and its CI. Taken together, PLII proved to be the most efficient inhibitory protein. In other cases, the MBC of crude extract was the same as the rest of pure proteins. PL-proteins turned out to be active not only against all tested bacterial strains but surprisingly also against some strains that are generally resistant to conventional antibiotics, such as S. aureus CI, E. faecalis CI, P. vulgaris CI, E. cloacae ATCC 10699, E. cloacae CI, E. aerogenes ATCC 13048, E. aerogenes $\mathrm{CI}$, and $P$. aeruginosa CI. RBC lysis and viability MTT assays were performed on human RBC and lymphocytes, respectively, treated with PL-proteins at the concentrations that produced bactericidal activity. After $24 \mathrm{~h}$ treatment with PL-proteins, lymphocyte viability was at least $80 \%$, while a maximum RBC lysis of only $2 \%$ was observed. Given the very low toxicity of these proteins at the concentrations which produced bactericidal activity, for their possible therapeutic use, we investigated their site of action in the bacterial cell. In order to evaluate whether PL-proteins enter the bacteria or act at the cell surface, S. aureus (ATCC 6738) and E. coli (ATCC 8739) were incubated in the presence of DEAC,SE-PL-protein conjugate and a uniform distribution of fluorescence was observed on the cell surface, as well as inside the cell. These results are in agreement with those shown in the literature on other basic molecules (Mitchell et al., 2000; Conte et al., 2007). The molecules with bactericidal activity are mainly positively charged peptides and by virtue of their hydrophobic and hydrophilic sides are able to be soluble in aqueous environments and also to enter lipid-rich membranes (Izadpanah \& Gallo, 2005). Our results, obtained by fluorescence microscopy, indicate that PL-proteins could depolarize the bacterial cytoplasmic membrane and cause cell lysis, as shown for protamines (Pink et al., 2014), or enter the cells for possible interaction with some intracellular target (Zasloff, 2002). The results of our nucleotide leakage assay (Fig. 6) showed that after treatment with PL-proteins for both bacteria, the nucleotide leakage was observed. This was particularly noticeable for $S$. aureus cells for which the amount of leaked nucleotides increased in a dose dependent manner. We used $3.4 \mathrm{mM}$ EDTA as a positive control. EDTA is a metal chelator that removes metal cations in the cell wall causing nucleotide leakage from the cell (Gray \& Wilkinson, 1965). Based on these data, PL-proteins could be acting at the bacterial membrane level, as previously shown for the Ac-FRWWHR-NH2 antimicrobial peptide with a model membrane systems and bacte- rial cells by Rezansoff and others (Rezansoff et al., 2005). It will be necessary to prove PL-protein action on bacterial membranes in future experiments, such as assays involving fractionation of membranes. Since PL-proteins also enter bacterial cells, it cannot be excluded that the mechanism of their action could depend on their interaction with an intracellular component. Indeed, since the natural function of PL-proteins is to bind nucleic acids, it is reasonable to suggest that they could affect some cellular processes, such as replication, transcription or translation, in the target cells. Such an effect has been previously shown for indolicidin, a proline and arginine rich antimicrobial peptide isolated from cytoplasmic granules of bovine neutrophils, which inhibits DNA synthesis (Subbalakshmi and Sitaram,1998). After all, the results of our EMSA and REMSA experiments confirmed that PL-proteins had affinity for bacterial nucleic acids (Fig. 5). However, since different size nucleic acid particles were used in these assays, we cannot establish for which nucleic acids the PL-proteins have higher affinity.

Antibacterial proteins have a potential as alternative treatments to standard antibiotic therapies and therefore it is important to define if there are issues with delivery of these agents inside the body. Oral administration would most likely result in the proteins being degraded in the digestive system. In order to analyze this aspect we generated an in vitro model of gastrointestinal digestion of PL-proteins. The digest included PL-IV together with a mixture of peptides probably deriving from PL-II and PL-III, and were tested on S. aureus (ATCC 6738) and E. coli (ATCC 8739) which were used as Gram-positive and Gram-negative representatives, respectively. The digest showed the same bactericidal activity against Staphylococcus aureus, but was lower for Escherichia coli when compared to undigested proteins. Obviously, the influence of these proteins on the human digestive tract microbiome should be investigated in future studies. In conclusion, this work presents the first evidence obtained for Mytilus galloprovincialis of bactericidal activity of the PL-proteins. The discovery of antibiotics with novel mechanisms of action is a critical issue to overcome the serious problem of growing numbers of bacteria resistant to conventional antibiotics (Lohner \& Staudegger, 2001). Therefore it would be interesting to further understand the mechanism of action of these proteins and their effective targets in order to use them as bactericidal agents. Further experiments will be also required to better analyze the bactericidal activity of digested PL-proteins against other bacterial strains. We cannot exclude that bacteria could become resistant to these proteins in the environment but further experiments will be necessary to address this which could be the focus of our future studies.

\section{Declaration of conflicting interest}

The authors declare that there is no conflict of interest.

\section{Acknowledgements}

The authors wish to thank EUROFISH NAPOLI S.R.L. Baia, in Naples for providing M. galloprovincialis specimens and the Plant Pathology Department of the University Federico II, Naples - Italy for providing the clinical isolates of bacteria.

\section{Acknowledgements of Financial Support}

This work was performed with departmental funds number: 000020--PRD-2017-M-PISCOPO_001_001 awarded to Marina Piscopo (Dept. Biology; University of Napoli Federico II; Italy). 


\section{REFERENCES}

Ausió J (1986) Structural variability and compositional homology of the protamine-like components of the sperm from the bivalve mollusks. Comp Biochem Physiol 85B: 439-449

Ausió J (1995) Histone H1 and the evolution of the nuclear sperm specific proteins, In Advances in Spermatozoal. Phyl and Tax 166: $501-514$

Ausió J (1999) Histone H1 and evolution of sperm nuclear basic proteins. J Biol Chem 274: 31115-31118. http://doi.org/10.1074/ jb.274.44.31115.

Ausió J, McParland R (1989) Sequence and characterization of the sperm-specific protein from Mytilus calïiornianus. Eur I Biochem 182. 569-576. http://doi.org/10.1111/j.1432-1033.1989.tb14865.x

Ausió J, Subirana JA (1982) A high molecular weight nuclear basic protein from the bivalve mollusc Spisula solidissima. I Biol Chem 25: 2802-2805. http://doi.org/10.1021/bi0360455

Barsotti G, Meluzzi C (1968) Osservazioni su Mytilus edulis L. e Mytilus galloprovincialis Lamarck. Conchiglie 4: 50-58

Basile A, Loppi S, Piscopo M, Paoli L, Vannini A, Monaci F, Sorbo S, Lentini M, Esposito S (2017) The biological response chain to pollution: a case study from the "Italian Triangle of Death" assessed with the liverwort Lunularia cruciata. Environ Sci Pollut Res Int 24: 26185-26193. http://doi.org/10.1007/s11356-017-9304-y

Basile A, Vuotto M.L, Violante U, Sorbo S, Martone G, Castaldo Cobianchi R (1997) Antibacterial activity in Actinidia chinensis, Feijoa sellowiana and Aberia caffra. International Journal of Antimicrobial Agents 8: 199-203. http://doi.org/10.1016/S0924-8579(97)00376-2

Carbone A, Fioretti F.M, Fucci L, Ausiò J, Piscopo M (2012) High efficiency method to obtain super coiled DNA with a commercial plasmid purification kit. Acta Biochim Polon 59: 275-278

Carlos S, Hunt DF, Rocchini C, Arnott DP, Ausio J (1993 b) Posttranslational cleavage of a histone H1-like protein in the sperm of Mytilus. I Biol Chem 268: 195-199

Carlos S, Jutglar L, Borrell I, Hunt DF, Ausio J (1993 a) Sequence and characterization of a sperm-specific histone H1-like protein of Mytilus californianus. I Biol Chem 268: 185-194

Carmona-Ribeiro AM, De Melo Carrasco LD (2013) Cationic Antimicrobial Polymers and Their Assemblies. Int J Mol Sci 5: 9906-9946. http://doi.org/10.3390/ijms14059906

Charlet M, Chernysh S, Philippe H, Hetru C, Hoffmann JA, Bulet P (1996) Innate immunity. Isolation of several cysteine-rich antimicrobial peptides from the blood of a mollusc, Mytilus edulis. I Biol Chem 271: 21808-21813 http://doi.org/10.1074/jbc.271.36.21808

Conte B, Sorbo S, Piscopo M, Rabbito D, De Ruberto F, Guerriero G, Basile A (2017) Antioxidant activity and ultrastructural alterations in the biosensor Lemna minor L. exposed in bags in Sarno river (South Italy). FEB 26: 225-236

Conte M, Aliberti F, Fucci L, Piscopo M (2007) Antimicrobial activity of various cationic molecules on foodborne Pathogens. World Microbiol Biotechnol 23: 1679-1683. http://doi.org/10.1007/s11274007-9415-6

Eirin-Lo' pez JM, Frehlick LJ, Chiva M, Saperas N, Ausiò J (2008) The sperm proteins from Amphioxus Mirror its basal position among chordates and redefine the origin of vertebrate protamines. Mol Biol Evol 25: 1705-1713. http://doi.org/10.1093/molbev/msn121

Eirin-Lo'pez JM, Lewis JD, Howe le A, Ausio J (2006) Common phylogenetic origin of Protamine-like (PL) proteins and histone $\mathrm{H} 1$ : evidence from bivalve PL genes. Mol Biol Evol 23: 1304-1317. http:// doi: $10.1093 / \mathrm{molbev} / \mathrm{msk} 021$

El-Gamal MI, Abdel-Maksoud MS, Oh CH (2013) Recent advances in the research and development of marine antimicrobial peptides. Curr Top Med Chem 13: 2026-2033. http://doi.org/10.2174/1568026 6113139990127

Fioretti FM, Febbraio F, Carbone A, Branno M, CarratoreV, Fucci L, Piscopo M (2012) A sperm nuclear basic protein from the sperm of the marine worm Chaetopterus variopedatus with sequence similarity to the arginine-rich $\mathrm{C}$-termini of chordate protamine-likes. $D N A$ Cell Biol 31: 1392-1402. http://doi.org/10.1089/dna.2011.1547

Gray GW, Wilkinson SG (1965) The action of Ethylenediaminetetraacetic acid on Pseudomonas aeruginosa. I Appl Bacteriol Microbiol 28: 153-164. http://doi.org/10.1111/j.1365-2672.1965.tb02138.x

Hubert F, Noel T, Roch P (1996) A member of the arthropod defensin family from edible Mediterranean mussels Mytilus galloprovincialis). Eur J Biochem 240: 302-306. http://doi.org/10.1111/j.14321033.1996.0302h.x

Iijima R, Kisugi J, Yamazaki M (2003) A novel antimicrobial peptide from the sea hare Dolabella auricularia. Dev Comp Immunol 27: 305 311. http://doi.org/10.1016/S0145-305X(02)00105-2

Izadpanah A, Gallo RL (2005) Antimicrobial peptides. I Am Acad Dermatol. 52:381-390. http://doi.org/10.1016/j.jaad.2004.08.026.

Kamiya H, Muramoto K, Yamazaki M (1986) Aplysianin-A, an antibacterial and antineoplastic glycoprotein in the albumen gland of a sea hare, Aplysia kurodai. Experientia 42: 1065-1067. http://doi. org/10.1007/BF01940736
Kubota Y, Watanabe Y, Otsuka H, Tamiva T, Tsuchiva T, Matsumoto JJ (1985) Purification and characterization of an antibacterial factor from snail mucus. Comp Biochem Physiol. 82(2): 345-348. http://doi. org/10.1016/0742-8413(85)90173-2.

Lewis JD, Ausió J (2002) Protamine-like proteins: evidence for a novel chromatin structure. Biochemistry Cell Biol. 80(3):353-361. http://doi. org/10.1139/o02-083.

Lewis JD, McParland R, Ausió J (2004) PL-I of Spisula solidissima, a highly elongated sperm-specific histone H1. Biochem. 43(24):7766-75. http://doi.org/10.1021/bi0360455.

Liu Y, Peterson DA, Kimura H, Schubert D (1997) Mechanism of cellular 3-(4,5-dimethylthiazol-2-yl)-2,5-diphenyltetrazolium bromide (MT'T) reduction. J Neurochem 69(2):581-93. http://doi.org/10.1046/ j.1471-4159.1997.69020581.x

Lohner K, Staudegger E (2001) Development of Novel antimicrobial agents: emerging strategies. Horizon Scientific Press, Wymondham, United Kingdom.

Maresca V, Fusaro L, Sorbo S, Siciliano A, Loppi S, Paoli L, Monaci F, Karam EA, Piscopo M, Guida M, Galdiero E, Insolvibile M, Basile A (2018) Functional and structural biomarkers to monitor heavy metal pollution of one of the most contaminated freshwater sites in Southern Europe. Ecotoxicol Environ Saf. 163:665-673. http://doi. org/10.1016/j.ecoenv.2018.07.122

Mitchell DJ, Kim DT, Steinman L, Fathman CG, Rothbard JB (2000) Polyarginine enters cell more efficiently than other polycationichomopolymers. J Pept Res. 56(5):318-325. http://doi.org/10.1034/ j.1399-3011.2000.00723.x.

Miura T, Iohara K, Kato T, Ishihara KI, Yoshinari M (2010) Basic peptide protamine exerts antimicrobial activity against periodontopathic bacteria. J. Biom. Science and Eng. 3:1069-1072. http://doi. org/10.4236/jbise.2010.311138.

Mogensen C, Carlos S, Ausio J (1991) Microheterogeneity and interspecific variability of the nuclear sperm proteins from Mytilus. FEBS Lett. 282(2):273-6.

Murray PR, Baron EJ, Pfaller MA, Tenover FC, Yolken RH (1995) Manual of Clinical Microbiology Sixth Edition. American Society for Microbiology.

Oliveira AV, Silva AP, Bitoque DB, Silva GA, Rosa da Costa AM (2013) Transfection efficiency of chitosan and thiolated chitosan in retinal pigment epithelium cells: A comparative study. J Pharm Bioallied Sci. 5(2):111-118. http://doi.org/10.4103/0975-7406.111823.

Phelan JJ, Colom J, Cozcolluela C, Subirana JA, Cole RD (1974) A lysine-rich protein from spermatozoa of the mollusc Mytilus edulis. I Biol Chem. 249:1099-1102.

Pink AD, Fida MH, Quinn BE, Winterhalter M, Mohad MB, Gill TA (2014) Interaction of protamine with gram-negative bacteria membranes: possible alternative mechanisms of internalization in Escherichia coli, Salmonella typhimurium and Pseudomonas aeruginosa. I Pept Sci. 20:240-250. http://doi.org/10.1002/psc.2610.

Piscopo M, Conte M, Di Paola F, Conforti S, Rana G, De Petrocellis L, Fucci L, Geraci G (2010) Relevance of Arginines in the Mode of Binding of H1 Histones to DNA. DNA Cell Biol 29:339-347. http://doi.org/10.1089/dna.2009.0993

Piscopo M, De Petrocellis L, Conte M, Pulcrano G, Geraci G. (2006) On the possibility that $\mathrm{H} 1$ histone interaction with DNA occurs through phosphates connecting lysine and arginine side chain groups. Acta Biochim Polonica. 53(3):507-13.

Piscopo M, Notariale R, Rabbito D, Ausió J, Olanrewaju OS, Guerriero G (2018c) Mytilus galloprovincialis (Lamarck, 1819) spermatozoa: hsp70 expression and protamine-like protein property studies. Environ Sci Pollut Res Int. 25(13):12957-12966. http://doi.org/10.1007/ s11356-018-1570-9

Piscopo M, Notariale R, Troisi J (2017) hsp70 AS New Cadmium Bioaccumulation Marker to prevent the risks of Mussels Consumption in Human Nutrition. Madridge J Clin Res 1(2): 39-45. http://doi. org/10.18689/micr.2017-107

Piscopo M, Ricciardiello M, Palumbo G, Troisi J (2016) Selectivity of metal bioaccumulation and its relationship with glutathione S-transferase levels in gonadal and gill tissues of Mytilus galloprovincialis exposed to Ni (II), Cu (II) and Cd (II). Rendiconti Lincei Scienze Fisiche e Naturali 27:737-748. http://doi.org/10.1007/s12210-016-0564-02 2015

Piscopo M, Tenore GC, Notariale R, Maresca V, Maisto M, De Ruberto F, Heydaric M, Sorbo S, Basile A (2018a) Antimicrobial and antioxidant activity of proteins from Feijoa sellowiana Berg. fruit before and after in vitro gastrointestinal digestion. Nat Prod Res "in press". http://doi.org/10.1080/14786419.2018.1543686

Piscopo M, Trifuoggi M, Notariale R, Labar S, Troisi J, Giarra A, Rabbito D, Puoti R, de Benedictis D, Brundo MV, Basile A, Good KV, Ausió J, Guerriero G (2018b) Protamine-like proteins analyses as emerging biotechnique for cadmium impact assessment on male mollusk Mytilus galloprovincialis (Lamarck 1819). Acta Biochim Pol 65: 259-267. https://doi.org/10.18388/abp.2017_2533

Piscopo M, Trifuoggi M, Scarano C, Gori C, Giarra A, Febbraio F (2018d) Relevance of arginine residues in $\mathrm{Cu}(\mathrm{II})$-induced DNA 
breakage and Proteinase $\mathrm{K}$ resistance of $\mathrm{H} 1$ histones. Sci Rep 8: 7414. http://doi.org/10.1038/s41598-018-25784-z

Poirier AC, Schmitt P, Rosa RD, Vanhove AS, Kieffer-Jaquinod S, Rubio TP, Charrière GM, Destoumieux-Garzón D (2014) Antimicrobial histones and DNA traps in invertebrate immunity: evidences in Crassostrea gigas. J Biol Chem 289: 24821-24831. http://doi. org/10.1074/jbc.M114.576546

Potter R, Truelstrup Hansen L, Gill TA (2005) Inibition of foodborne bacteria by native and modified protamine: importance of electrostatic interactions. Int J Food Microbiol 103: 23-34. http://doi. org/10.1016/j.ijfoodmicro.2004.12.019

Raiola A, Meca G, Mañes J, Ritieni A (2012) Bioaccessibility of Deoxynivalenol and its natural co-occurrence with Ochratoxin $A$ and Aflatoxin B1 in Italian commercial pasta. Food Chem Toxicol 50: 280287. http://doi.org/10.1016/j.fct.2011.09.031

Rezansoff AJ, Hunter HN, Jing W, Perk LY, Kim SC, Vogel HJ (2005) Interactions of the antimicrobial peptide Ac-FRWWHRNH2 with model membrane systems and bacterial cells. J Pept Res 65: 491-501. http://doi.org/10.1111/j.1399-3011.2005.00263.x

Rocchini C, Rice P, Ausió J (1995) Complete sequence and characterization of the major sperm nuclear basic protein from Mytilus trossulus. FEBS Lett 363: 37-40. http://doi.org/10.1016/00145793(95)00275-E

Rose-Martel M, Hincke MT (2014) Antimicrobial histones from chicken erythrocytes bind bacterial cell wall lipopolysaccharides and lipoteichoic acids. Int J Antimicrob Agents 44: 470-472. http://doi. org/10.1016/j.ijantimicag.2014.07.008
Salvati D, Conforti S, Conte M, Matassa DS, Fucci L, Piscopo M (2008) Self-association of Chaetopterus variopedatus sperm histone H1like Relevance of arginine content and possible functional role. Acta Biochim Pol 55: 701-706.

Smit AJ (2004) Medicinal and pharmaceutical uses of seaweed natural products: A review. J Appl Phycol 16: 245-262. http://doi. org/10.1023/B:JAPH.0000047783.36600.ef

Subbalakshmi C, Sitaram N (1998) Mechanism of antimicrobial action of indolicidin. FEMS Microbiol Lett 160: 91-96. http://doi. org/10.1111/j.1574-6968.1998.tb12896.x

Tepe B, Donmez E, Unlu M, Candan F, Daferera D, Vardar-Unlu $G$ (2004) Antimicrobial and antioxidative activities of the essential oils and methanol extracts of Salvia cryptantha, (MontbretAucher ex Benth.) and Salvia multicaulis (Vahl). J Food Chem 84: 519-525. http://doi.org/10.1016/S0308-8146(03)00267-X

Vassalli QA, Caccavale F, Avagnano S, Murolo A, Guerriero G, Fucci L, Ausió J, Piscopo M (2015) New Insights into ProtamineLike Component Organization in Mytilus galloprovincialis's sperm Chromatin. DNA Cell Biol 34: 162-169. http://doi.org/10.1089/ dna.2014.2631

Wang G (2014) Human antimicrobial peptides and proteins Guangshun Wang. Pharmaceuticals 7: 545-594. http://doi.org/10.3390/ ph7050545

Washington DC, Washington II JA, Warren E, Karlson AG (1972) Stability of barium sulfate turbidity standards. Appl Microbiol 24: 1013

Zasloff M (2002) Antimicrobial peptides of multicellular organisms. Nature 415: 389-395. http://doi.org/10.1038/415389a 